\title{
ien
}

\section{THE IMPACT OF INNOVATION BROKERS ON INTERFIRM NETWORK EVOLUTION}

\section{IE Business School Working Paper}

WP11-02

19-01-2011

\author{
Carl Joachim Kock \\ IE Business School \\ Strategy Department \\ María de Molina 12, $4^{\circ}$-D \\ 28006 Madrid
}

carl.kock@ie.edu

\author{
Remzi Gözübüyük \\ IE Business School \\ Strategy Department \\ María de Molina 12, 4º-D \\ 28006 Madrid
}

remzi.gozubuyuk@ie.edu

\begin{abstract}
In recent years, the development of the idea of "Open Innovation"(Chesbrough, 2004; 2006) lead to the emergence of "Innovation brokers" who connect those seeking for solutions with a rather large number of potential knowledge suppliers. In this paper we analyze the implication that the existence of such Innovation brokers has on other organizational interchanges firms may engage in. Specifically, we ask how the interorganizational network of a particular firm evolves over time if they use an Innovation broker or not. Apart from contributing to both, network theory by shedding light on the evolution of network ties, and the innovation literature by adding to our understanding of how knowledge flows develop over time, our work should also have rather practical implications for Innovation brokers themselves and for their clients.
\end{abstract}

Keywords: Interorganizational networks, open innovation, network evolution.

Copyright (C) 2011 by Remzi Gözübüyük and Carl Joachim Kock, professors at IE Business School.

This working paper is distributed for purposes of comment and discussion only. It may not be reproduced without permission of the copyright holder. Copies of working papers are available from the authors.

Printed at IE Business School, Madrid, Spain. Please, do not reproduce or circulate without permission. 
In recent years, the term "Open Innovation" has become an increasingly popular description for an emerging paradigm that suggests that firms move away from a closed, protective and firm centered innovation system towards a model that embraces the potential of joint innovation or at least extensive knowledge interchanges with other organizations (e.g., Chesbrough, 2004, 2006a,b). The general idea is that firms can enhance their innovative performance by importing knowledge from firm external sources (such as suppliers, customers or universities; e.g., Laursen and Salter, 2004, 2006) and further benefit financially by selling to other firms internally generated "surplus" innovations (i.e., ideas that cannot be usefully applied within the firm's current business model; e.g., Lichtenthaler, 2006, 2007).

Based on these general ideas, a number of inter-organizational developments can be observed recently. On one hand, firms attempt to spin "Innovation nets" around themselves in order to bind a variety of potential suppliers of ideas to themselves. On the other hand, third parties attempt to become "Innovation brokers" who connect those seeking for solutions with a rather large number of potential knowledge suppliers. This latter phenomenon, exemplified by new companies such as InnoCentive (Allio, 2004), constitutes a near-perfect "structural hole" as we know it from network literature (Burt, 1992). In fact, by focusing solely on exploiting the informational advantage of connecting two or more actors who do not have direct ties, innovation brokers purely benefit from the information (and to some extent also the power) advantage of being a structural hole - they do not, however, benefit from the ties in any more direct way, as, for example, firms in a network of alliances would. In this paper we analyze the implication that the existence of such Innovation brokers has on other organizational interchanges firms may engage in. Specifically, we ask how does the inter-organizational network of a particular firm evolve over time if they use an Innovation broker or not. Apart from contributing to both, network theory by shedding light on the evolution of network ties, rather than just looking at static comparisons of various network types, and the innovation literature by adding to our understanding of how knowledge flows develop over time, our work should also have rather practical implications for Innovation brokers themselves and for their clients. 


\section{LITERATURE \& THEORY}

A number of high profile firms such as Procter \& Gamble (P\&G), Philips, IBM, Nokia or Endesa have already embraced the idea (e.g., Huston \& Sakkab, 2006; own interviews; www.cide.endesa.es) that a high degree of “openness” can help shorten innovation lags, provide overall new ideas, or help to cover own R\&D expenses. Some of these firms have created rather explicit new organizational structures to aid them in particular in reaching out to other entities that could be sources of new ideas. Endesa, a leading Spanish power company, for example, has created an innovation network that brings together more than 50 world renowned high technology firms (among them IBM, Siemens, Alcatel-Lucent, etc.) that are interested in a closer cooperation with Endesa. These partner firms pay an annual fee on the order of several ten thousand Euro to benefit from the various events that Endesa sponsors within this network. In addition to an annual innovation congress, Endesa also shares a host of in-depth technical information on its own innovation status and particularly its innovation needs for the future. If any of the partner firms recognizes an opportunity to solve any of Endesa's specific problems, a bilateral innovation project is started (own interview with Endesa). This is an example of a firm centered innovation network that leads to the development of comparatively strong ties between the firm in the center and the potential suppliers of knowledge. A somewhat different model is currently being developed by P\&G, which, as Huston and Sakkab report in a series of articles and interviews (2006; RTM, 2007), has embraced open innovation ideas to such an extent that they already derive more than $50 \%$ of their innovation at least in part from knowledge or ideas developed outside of their firm boundaries. To achieve this, $P \& G$ has build up internal capacities at spotting valuable external knowledge sources by dedicating about 70 persons to a “Technology Entrepreneurs Network” which actively scouts for new ideas, or bringing back retirees to once more aid $P \& G$ in development activities. The latter approach has even grown into a business called "YourEncore" that now creates a network among retirees and at least 15 other firms. In addition to forming their own instruments, P\&G is also actively using existing external Innovation Brokers like “Innocentive”, or "NineSigma”.

It is these Innovation Brokers that form the focus of our paper. Dominating firms like P\&G appear to be explicitly engaged in shaping the nature of the firm interaction that will ensue as 
more firms scramble to take advantage of the promises of open innovation. While P\&G follows seemingly a strategy of mixing various approaches (creating own networks, having dedicated technology scouts, but also just being a “customer” of commercial innovation brokers), other large firms, like Endesa, appear to be trying to create more of an exclusive club around themselves. What, however, should we expect of the average firm that wants to source outside knowledge? Will they become simple customers of innovation brokers and rely more or less completely on such arrangements, or will they likewise try to form their own networks (i.e., strong links with several other entities), perhaps even at the same time that they peruse brokers? Moreover, recent studies theorized and empirically demonstrated the importance that firms' interorganizational networks have for their innovativeness (Ahuja, 2000: Reagans and Zuckerman, 2001; Zaheer and Bell, 2005). Our conjecture in this paper is that a firm's relationships with the innovation brokers will significantly change its network structure, particularly the use of strong and weak ties (Granovetter, 1973). This will happen as these innovation brokers will lead to an institutionalization of trust (Zucker, 1986) by carefully designing the rules of exchange between partners and thus to a decrease for the need for interorganizational trust in exchange relationships (Ring and van de Ven, 1994; Zaheer, McEvily, and Perrone, 1998). This will decrease the search costs and firms will start to reach distant parts of the network by weak ties that they create through these innovation brokers. As a result, we expect an initial decrease in the importance of existing strong ties. Later on, as they discover new partners, they may strengthen some of these relationships, and consequently increase the number of strong ties. This cycle through the use of strong and weak ties will then likely be repeated over the long run. We explain these ideas further below.

If a client firm can rely on one (or more) Innovation broker to always identify new suppliers of knowledge, a straightforward conjecture would be that it would not be of benefit to the client to maintain (or establish in the first place) its own network of strong ties to organizations that may have knowledge needed by the focal firm in the future. Behind this reasoning is a very simple cost-benefit calculation - maintaining strong ties has the advantage that transaction costs (Williamson, 1975) of finding new exchange partners, contracting with them and then enforcing the contracts is minimized, as trust of repeated transactions reduces governance costs, and the search and contracting costs naturally fall away as the same partner is used over and over. In addition, over time, partner-specific absorptive capacity (Dyer and Singh, 1998; Cohen \& 
Levinthal, 1990) is likely to emerge; i.e., as firms start to understand each other increasingly well (they become acquainted to each others knowledge bases, communication systems, etc.), learning and technology adoption between the partners are facilitated. On the other hand, constantly dealing with the same set of exchange partners also has some costs - primarily, there is no guarantee that the existing partners have the best ideas or knowledge in any given context; here, a broader search would perhaps yield more valuable knowledge that is not available in an existing set of strong ties. In addition, as partners build up absorptive capacity with respect to the focal firm, the risk of leaking (too much) information into these "partner" firms increases with the strength and duration of the tie.

Using an innovation broker, however, has a different economic logic. On one hand, an innovation broker can potentially generate a very large variety of external views on a problem which could result in rather well targeted, rather valuable knowledge to the client (in fact, firms like InnoCentive strongly advertise with examples where some outside inventors already had the solutions in the drawer that client firms initially tried unsuccessfully to create in-house - see Allio, 2004). Furthermore, by keeping seekers and providers of knowledge anonymous until a deal has been reached, knowledge spillovers are minimized. Accordingly,

H1: Client firms that work with innovation brokers will reduce the number of direct strong ties they have over time.

However, as client firms start working with an innovation broker, they will also come into direct contact with providers of knowledge since, once the broker identifies a match between knowledge needs and a potential supplier, the two parties must be brought together to actually carry out an act of joint knowledge creation. In other words, knowledge needs posted with the innovation broker rarely will meet with "ready made" solutions on the supplier side; rather, suppliers with a potential ability to meet the posted requirements of the knowledge seeker may come forward, and the two parties then need to jointly work on the actual solution (innocentive.com). Such a contact, if successful, would seem to be likely to entice the two entities (knowledge seeker and supplier) to consider working together again in the future, most likely without further moderation by the Innovation broker (particularly, since this would avoid the charges the innovation broker levies for its services). Accordingly: 
H2: Client firms that work with innovation brokers will increase the number of direct strong ties they have over time (the new strong ties being primarily entities introduced via the innovation broker).

Accordingly, to the extent that firms develop such strong ties and focus much of their attention on working with a specific set of knowledge generation partners, they will likely feel a lower need of working with an innovation broker. Yet, over time, the problem of strong ties, i.e. a focus on a narrow set of partners and their specific experience may lead to too much of a concentration on exploitation of existing ideas, rather than an exploration (March, 1991) of new areas. Thus, with time, firms may renew their interest in working with innovation brokers to benefit from the lager breadth of potential knowledge sources that these brokers offer access to. Hence:

H3: If client firms subsequent to working with an innovation broker increase their strong ties, then their relationship with the innovation broker will fluctuate over time between strong and weak.

Furthermore, as suggested above, innovation brokers offer access to a large variety of ideas that may form the basis for more exploratory knowledge generation in a focal firm:

H4: Client firms that utilize and Innovation broker will engage in more exploration than other firms.

\section{EMPIRICAL APPROACH}

In order to empirically test our arguments, we will collect data from both the innovation brokers and the firms that participate and do not participate in open innovation systems. We will also use secondary data to map the alliance network.

Our arguments suggest that we should test them over time. Since, the open innovation idea is fairly new, we would like to triangulate by also comparing the alliance networks of companies that participate in open innovation systems with similar companies that do not participate in them.

In order to measure H1, we will compare the alliance networks of companies before and after they participate in the open innovation systems. We should expect a decrease in the strong ties (measured by multiple alliances signed with the same company and whether the alliance involves 
equity or not) immediately. To triangulate, we will also compare the alliance networks of companies that participate and that do not participate in the open innovation systems.

In order to measure H2, we will look at how many new alliances are signed before and after the companies participate in the open innovation systems. We will also compare the new alliance formation rate of companies that participate in and that do not participate in open innovation systems.

In order to test $\mathrm{H} 3$, we will compare the variance in strong versus weak tie ratio of the companies that participate in open innovation systems with the same ratio of the companies that do not participate.

In order to test $\mathrm{H} 4$, we will compare the $\mathrm{R} \& \mathrm{D}$ to revenues ratio of companies before and after they participate in open innovation systems. We will also compare the same ration between companies that participate in open innovation systems and that do not.

\section{CONCLUSIONS}

In this paper, we argue that the success of open innovation brokers will alter the network structure of high technology firms. The major effects of these brokers will be to institutionalize trust at the network level and therefore lower the needs for interorganizational trust (Ring and van de Ven, 1994; Zucker, 1986; Zaheer, McEvily, and Perrone, 1998). This change creates a favorable environment for exploration (March, 1991) in the short run and a freer hand to manage exploration and exploitation in the long run. Firms that participate in these open innovation systems will have lower search costs with institutionalized trust and therefore will have an upper hand in overcoming local search and managing the tradeoff between exploration and exploitation more effectively. 


\section{References}

Ahuja, G. 2000. Collaboration networks, structural holes, and innovation: A longitudinal study. Administrative Science Quarterly, 45: 425-455.

Allio, R. J. 2004. CEO interview: The InnoCentive model of open innovation. Strategy \& Leadership, 32(4): 4-9.

Burt, R. S. (1992). Structural Holes: The Social Structure of Competition. Cambridge, Massachusetts, and London, England, Harvard University Press.

Chesbrough H. 2004. Managing open innovation. Research Technology Management 47 (1): 2326.

Chesbrough H. 2006a. Open Business Models: How to Thrive in the New Innovation Landscape. Harvard Business School Press: Boston, MA.

Chesbrough H. 2006b. Open Innovation: The new imperative for creating and profiting from technology. Harvard Business School Press: Boston, MA.

Cohen, W. M., D. A. Levinthal. 1990. Absorptive capacity: A new perspective on learning and innovation. Admin. Sci. Quart., 35(1): 128-152.

Dyer, J. H., Singh, H. 1998. The relational view: Cooperative strategy and sources of interorganizational competitive advantage. Academy of Management Review, 23(4): 660679.

Granovetter, M. S. 1973. The Strength of Weak Ties. The American Journal of Sociology, 78(6): 1360-1380.

Huston, L., Sakkab, N. 2006. Connect and develop: Inside Procter \& Gamble’s new model for Innovation. Harvard Business Review, 84(3): 58-66.

Laursen K, Salter AJ. 2004. Searching high and low: what types of firms use universities as a source of innovation? Research Policy 33 (8): 1201-1215.

Laursen, K., Salter, AJ. 2006. Open for Innovation: The role of openness in explaining innovation performance among UK manufacturing firms. Strategic Management Journal 27(2): 131-150.

Lichtenthaler, U. 2006. Technology exploitation strategies in the context of open innovation. International Journal of Technology Intelligence and Planning, 2 (1): 1-21.

Lichtenthaler, U. 2007. Hierarchical strategies and strategic fit in the keep-or-sell decision. 
Management Decision, 45 (3): 340-359.

March, J. G. 1991. Exploration and exploitation in organizational learning. Organ. Sci. 2(1): 7187.

Reagans, R. and E. W. Zuckerman. 2001. Networks, Diversity, and Productivity: The Social Capital of Corporate R\&D Teams. Organization Science, 12(4): 502-517.

Ring, P. S. and A. H. Van de Ven. 1994. Developmental Processes of Cooperative Interorganizational Relationships. Academy of Management Review, 19(1): 90-118.

RTM. 2007. Implementing Open Innovation; Interview with Huston and Sakkab. Research and Technology Management, March-April 2007: 21-25.

Williamson, O. E. 1975. Markets and Hierarchies: Analysis and Antitrust Implications. New York: MacMillan Free Press.

Zaheer, A. and G. G. Bell. 2005. Benefiting from Network Position: Firm Capabilities, Structural Holes, and Performance. Strategic Management Journal, 26(9): 809-825.

Zaheer, A., B. McEvily, Perrone. 1998. Does Trust Matter? Exploring the Role of Interorganizational and Interpersonal Trust on Performance. Organization Science, 9(2): 141-159.

Zucker, L. 1986. Production of Trust: Institutional Sources of Economic Structure, 1840-1920. Research in Organizational Behavior, 